\title{
頡口腔領域の悪性リンパ腫初診時臨床所見に関する検討
}

\author{
藤 原 成 祥・神 谷祐 司・大重日出男 \\ 加藤伸一郎・斉藤 輝 海・河 原恭子
}

\section{Clinical studies of the initial clinical findings of malignant lymphoma arising in the oral and maxillofacial region}

\author{
Shigeyoshi Fujiwara $\cdot$ Yuji Kamiya $\cdot$ Hideo Ohoshige \\ Shinichirou Kato $\cdot$ Terumi SaI'ro $\cdot$ Kyoko Kawahara
}

\begin{abstract}
Thirteen patients with malignant lymphoma (ML) consulted our department during the 7 years from June 1990 through May 1997. The initial clinical symptoms of the patients were analyzed retrospectively.

The results were as follows:

1. ML accounted for $8.7 \%$ of all malignant tumors of the oral and maxillofacial region at our department.

2 . The subjects consisted of 12 males and 1 female. Their mean age was 62 years.

3 . Of the 13 patients, 11 were pathologically confirmed as having non-Hodgkin's lymphoma and 2 as having Hodgkin's disease.

4. There were 3 nodal cases and 10 extranodal cases.

5 . The primary site of the tumor was the cervical lymph nodes in 3 cases, the gingiva in 6 , the hard and soft palate in 3 , and the buccal submucosa in 1 .

6 . Only one case was clinically diagnosed as malignant lymphoma. The initial clinical diagnosis in the remaining 12 cases was other malignant tumors in 6 cases, osteomyelitis in 3 , benign tumor in 2 , and lymphoadenitis in 1 .
\end{abstract}

Key words: malignant lymphoma (悪性リンパ腫), oral and maxillofacial region(顎口腔領域)

\section{緒言}

悪性リンパ腫（以下 ML とする）は,リンパ節ある いは節外リンパ組織に原発したリンパ性悪性腫湟の総 称である. 頭頸部はその好発部位の一つであり, とく に頸部リンパ節およびWaldeyer 扁桃輪には頻度が高 い疾患である。しかし, 頻度こそ少ないが1)，口腔に 初発した場合は種々の臨床病態を呈し確定診断に苦慮す る. 今回われわれは, 当施設で ML と診断した症例につ いて, その初発臨床像について検討したので報告する.

\section{対象および方法}

1990年 6 月から 1997 年 5 月までの 7 年間に当科を受 診し, 当科にて ML と診断した非ホジキンリンパ腫

姫路赤十字病院歯科口腔外科

(主任 : 神谷祐司)

Department of Dentistry and Oral Surgery, Himeji

Red Cross Hospital (Chief: Yuji Kamiya)

受付日: 平成 9 年 7 月 22 日
(NHL) 11例とホジキン病（HD）2 例，計13例を対象 とし, 初発部位, 初発症状, 受診までの経路, 初診時臨 床像, X線像, 初診時診断, 病理組織学的所見などの臨 床所見を retrospectiveに検討した。ただし他院にて すでに診断されていた将例は除外することとした。

\section{結果}

初診時臨床所見をまとめて表に示した（表 1 ）。

\section{1. 頻度}

同期間中に当科で悪性腫瘍と診断された症例は150例 で, そのうち ML は13例で全悪性腫場の $8.7 \%$ を占めてい た.

\section{2 . 性および年齢分布}

男性12例，女性1例で男性に圧倒的に多かった。年 歯は24歳から87歳で平均62歳であった。

\section{3 . 初発部位}

頸部リンパ節に関連した節内性のものが 3 例，その 他は節外性で, 上顎歯肉 3 例, 下顎歯肉 3 例, 口蓋 3 例, 
表 1 当科の悪性リンパ腫症例

\begin{tabular}{|c|c|c|c|c|c|c|c|c|c|c|}
\hline 症例 & 年齢 & 性別 & 節内 $/$ 外 & 初 発 部 位 & 来院経路, 来院前治療 & 視診型 & X線所見 & 初診時診断 & NHL $/ \mathrm{HD}$ & LSG 分類 \\
\hline 1 & & 男 & 節外 & 右下額歯肉 & 医科／他歯科にて拔歯 & 瘍 & 骨破銥像 & 下顎骨䯣炎 & NHL (B) & びまん性,バーキット型 \\
\hline 2 & & 男 & 節外 & 右上類歯肉 & 歯科／切開 & 瘍 & 骨破壊像 & 悪 性 腫 瘍 & NHL (B) & びまん性, 大細胞型 \\
\hline 3 & & 男 & 節外 & 右上䅡歯肉 & －歯科／治療なし & 瘍 & 所見なし & 墨 性 腫 瘍 & NHL (B) & びまん性, 大細胞型 \\
\hline 4 & & 男 & 節外 & 左下頻粦肉 & 歯科／義歯調整 & 瘍 & 骨破壊像 & 下類骨䯠炎 & NHL (T) & びまん性, 多形細胞型 \\
\hline 5 & & 男 & 節外 & 左下顎歯肉 & 歯科／抜歯 & 場 & 骨圧迫吸収 & 下嚬骨髄炎 & HD & \\
\hline 6 & & 女 & 節外 & 左上類歯肉 & 歯科／抜歯 & 爛 & 骨圧迫吸収 & 悪 性 腫 瘍 & NHL (B) & びまん性, 大細胞型 \\
\hline 7 & & 男 & 節外 & 煩 部 粘 膜下 & 紹介なし/なし & 粘膜下腫脹 & & 良 性 腫 瘍 & NHL (T) & びまん性, 大細胞型 \\
\hline 8 & & 男 & 節外 & 蓋 & 歯科／義歯調整，投薬 & 粘膜下腫脹 & 所見なし & 悪 性 腫 瘍 & NHL (B) & びまん性, 中細胞型 \\
\hline 9 & & 男 & 節外 & 軟 口 & 歯科／抜苗 & 爛 & 所見な L & 悪 性 腫 瘍 & NHL (T) & びまん性, 大細胞型 \\
\hline 10 & & 男 & 節外 & 硬 & 医科／治療なし & 粘膜下腫脹 & 所見なし & 悪 性 腫 瘍 & NHL (B) & 滤胞性, 中細胞型 \\
\hline 11 & & 男 & 節内 & 瓄部リンパ節 & 歯科／治療なし & 顠 部 腫 瘤 & & 良 性 腫 瘍 & NHL (B) & 濾胞性, 中細胞型 \\
\hline 12 & & 男 & 節内 & 䫇部リンパ節 & 医科／治療なし & 顠 部 腫 瘤 & & 悪性リンパ腫 & NHL (B) & びまん性, 大細胞型 \\
\hline 13 & & 男 & 節内 & 顠部リンパ節 & 歯科／治療なし & 䫟 部 腫 瘤| & & 頸部リンパ節 炎 & HD & \\
\hline
\end{tabular}

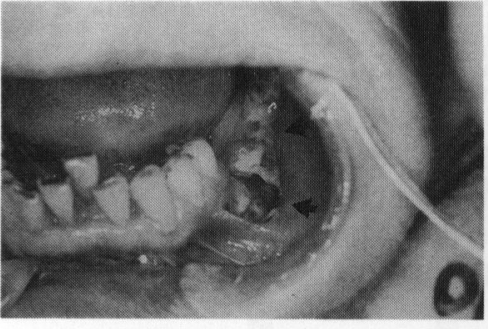

写真 1 症例 5 : 左下顎大臼歯部には 深い潰瘍を認めるが, 周囲の硬結はそ しい.

㚘部粘膜下 1 例であった.

\section{4. 来院経路, 来院前治療}

来院までの経路は歯科医院よりの紹介が 9 例と最も 多く, 院外の医科よりが 2 例, 院内他科よりが 1 例, 直 接来院したものが 1 例であった。治療なく紹介された ものが 6 例であったが, 4 例では抜歯を受け，1例で は切開処置を，2 例では義歯の調整を受けていた。

\section{5 . 初診時臨床視診型}

口腔内に何らかの病変を呈したものが10例であり， 7 例では潰瘍，糜爛を伴い臨床的に悪性腫瘍を強く疑 うものであった３例は粘膜下の腫脹として観察され た. その他 3 例は頸部リンパ節腫脹の症例であった。

\section{6 . 初診時X線所見}

歯肉に病変をもつ 6 例のうち 5 例では骨の破壊や吸 収などの所見を認めた. その他の症例では特に所見は 認めなかった

\section{7. 当科での初診時診断}

当科での臨床診断で ML を強く疑ったものは 1 例 のみであった，他悪性腫瘍を疑ったものが 6 例，骨䯣 炎 3 例, 良性腫瘍 2 例, 頸部リンパ節炎 1 例であった。

\section{8 . 病理組織学的所見}

非ホジキンリンパ腫 (NHL) が11例で, ホジキン病 (HD) が 2 例であった. NHL11例のうち T-cell 由来 が 3 例, B-cell 由来が 8 例あった. LSG 分類では濾胞
性が 2 例，びまん性が 9 例であっ た。

\section{9. 治療法}

13例の内, 11例は当院内科, 2 例は院外の内科へ紹介していた。 当院内科で治療を行った11例では 5 例で化学療法がなされ，3例で は放射線療法，1例では放射線療 法と化学療法併用, 年齢や全身状 態を理由に静観されたものが 2 例 であった。

\section{0. 予後}

当院で加療を行った11例のうち， 現病死 3 例, 他病死 1 例で, 不明の 1 例を除いて 6 例 では再発の徴候なく生存中である.

\section{考察}

頭頸部は ML の好発部位であり，特に頸部リンパ節 と Waldeyer 扁桃輪には高頻度である. 口腔外科より の報告で, 悪性腫瘍に占める $\mathrm{ML}$ の割合は，作田ら ${ }^{2)}$ は7.4\%, 戸塚ら ${ }^{3)}$ は6.3\%, 堂原ら ${ }^{4)}$ は $4.2 \%$, 南雲ら 5 ) は0.5\%，奥田ら ${ }^{6)}$ は8.6\%，荻場ら ${ }^{7)}$ は $4.5 \%$ などと報 告している. 当科では 7 年間の全悪性腫瘍患者 150 例のう ち8.7\%を占め，やや頻度が高いように思われた。性別， 年齢は男性が92\%，40歳以上が85\%と，男性に多く，中高 年に多いという諸家の報告と同様の結果であった $2 〜 7)$.

その発生部位は,リンパ節に発生する節内性と, リン パ節以外の節外性に分けられており，本邦の NHL での 統計ではほぼ半々であると言われている1)。しかし口腔 外科領域の NHL の報告では節外性が多く2 -7)，当科 では NHL11例のうち $80 \%$ が節外性と考えられる症例 であった。節外性 NHL の好発部位は扁桃, 鼻腔, 副鼻 腔，胃などである ${ }^{1)}$. 毛利ら ${ }^{1)}$ の報告によれば節外性 NHL440例のうち 6 例, $1.8 \%$ が口腔に見られたとして おり, 口腔は比較的にまれな部位と言える。しかし口 腔外科よりの報告では歯肉, 歯槽部が多くを占めてお 
$\eta^{2 \sim 7)}$, われわれが本疾患の第一発見者として重要 な位置にいることを示すものであると推察した．また HD の 2 例では 1 例は節内性， 1 例は節外性を呈して いた.

当科へ来院するまでの経路は, 歯科医院よりの紹介が 9 例と最も多かった，その他院内院外を含む他医科よりの 紹介が 3 例, 紹介なしに来院したものが 1 例であった.

来院前の治療は治療なく紹介されたものが 6 例であっ たが, 抜歯 4 例, 切開 1 例, 義歯調整 2 例と歯科医院で 歯性疾患として処置を受けたものが約半数あった，と くに歯肉に病変をもつ 6 例中 5 例では, なんらかの歯 科的処置が施されていた。

当科での初診時診断は, 節外性の 10 例では 6 例で初 診時より悪性腫瘍を疑い生検を施行した。しかし 3 例 では下顎骨骨髄炎とし，1例では良性腫瘍であった。 一般的には MLによる潰瘍は扁平上皮癌による潰瘍 とは異なり, 辺縁明暸で硬結を伴わない場合が多いと されている ${ }^{2,3)}$.このため炎症性疾患との鑑別が難し い場合が多いと考えられている.当科でも症例1.4.5な ど歯肉に潰瘍，糜爛を有した症例で臨床的，肉眼的に 硬結がそしいなどの理由で炎症性疾患と診断していた (写真 1 ). また文献的に検索が可能であった，歯肉に 病変を有する20例では 9 例 $2 \sim 8), 45 \%$ が炎症性疾患と 診断されており，あらためて鑑別診断の難しさを感じ た. 節内性の 3 例では, 1 例では初診時より多発するリ ンパ節を触知し, ML を強く疑った症例があったが, 他 の 2 例では良性疾患, 炎症性疾患を疑っていた。

歯肉に病変をもつ6例ではX線が撮影されていたが, 骨の破壊と思われる症例が 3 例, 辺縁が明瞭な吸収と 思われるものが 2 例, 所見を認めなかったものが 1 例 であった. MLのX線所見は一般に悪性腫崵, 骨髄炎 を思わせるびまん性の骨破壊像であり, 骨髄炎より骨 破壊の程度が大きいと言われている ${ }^{9)}$. しかし当科で は著明な吸収を認めたのは症例 5 のみで (写真 2 ), 他 の症例では吸収, 破壊は著明でなかった。

病理組織分類では, NHL11例のうち Bcell 由来が 8 例, Tcell 由来が 3 例であった. LSG 分類では, 滤胞性 が 2 例, びまん性が 9 例であった。滤胞性の 2 例はと もに中細胞型であった.びまん性の 9 例は, 大細胞型 が 6 例, 中細胞型が 1 例, 多形細胞型が 1 例, バーキッ ト型が 1 例であった。

本疾患は形態学的にはリンパ細胞由来の腫瘍であるが, 機能的には免疫担当組織の腫瘍であるといわれ ${ }^{10)}$, 局所 においては病変を形成することがあるが, 基本的には 血液疾患の一つであると考えられている，その治療に は全身にわたる的確な病期分類が肝要で，それにより 局所療法である放射線療法や, 全身療法である化学療 法が選択される.今回の 13 例は病期分類, 治療はすべ て内科に依頼していた。しかし初期の段階で, 病変が 限局する場合外科療法の選択も考えられる他, 切除に て病変の減量を行い, 放射線治療, 化学療法の効果を
高めることも可能であると考えている. そのためわれ われは, MLの好発部位を扱うものとして，常に鑑別 疾患の一つと考え, 的確かつ迅速な確定診断を行い, 早期治療開始へ向け関連各科と連係をとり, 治療に当 たることが重要であると思われる.

\section{結語}

今回1990年 6 月から 1997 年 5 月までの 7 年間に当科 で診断した ML13例について, その初発臨床像につい て検討を行った。

1. 同期間の悪性腫場患者は 150 名で, ML は8.7\%を 占めていた。

2. 男性12例, 女性 1 例で, 平均年齢は62歳であった.

3. 節内性が 3 例で, 節外性が10例であった. 節外性 のうち, 上顎歯肉 3 例, 下顎歯肉 3 例, 口蓋 3 例, 煩部 粘膜下 1 例であった。

4. 当科での初診時診断は悪性腫瘍を疑ったものが 6 例, ML としたものが1例であった. しかし 3 例では 骨髄炎，2 例では良性腫瘍，リンパ節炎 1 例であり，鑑 別診断の難しさを改めて感じた.

稿を終えるにあたり，本論文に対しご助言，ご指導いた だいた愛知学院大学歯学部, 口腔外科学第二講座, 河合幹 教授, 小木信美講師に深甚の謝意を表します.

\section{参 考 文 献}

1）毛利 昇, 島峰徹郎 : 節外性 non-Hodgkin リ ンパ腫. 日本臨床 41: 2569-2577 1983.

2）作田正義, 佐藤光信, 他：口腔領域に発生した 悪性リンパ腫の臨床的および病理組織学的研究. 日口外誌 38: 1859-1866 1992.

3）戸塚靖則, 富田喜内：顎, 口腔領域に生じた悪 性リンパ腫の 14 症例について. 日ロ外誌 25 : 631-643 1979.

4）堂原義美, 杉原一正,他：口腔領域に初発した と思われる悪性リンパ腫の臨床的病理組織学的 検討. 口科誌 31: 187-199 1982 .

5）南雲めぐみ, 伏島昇一, 他：口腔領域に生じた 悪性リンパ腫13症例の臨床ならびに病理組織学 的検討. 口科誌 36: 289-299 1987 .

6）奥田 孝, 戸井田 誠,他：当科における悪性 リンパ腫の臨床的検討。口科誌 39: 648-652 1990.

7）荻場明子,田村 稔,他：当科における悪性リ ンパ腫症例の初発臨床像に関する検討. 日口外 誌 39: 1206-1212 1993 .

8）花沢康雄,伊藤公介,他：最近 6 年間に経験し た顎口腔領域の悪性リンパ腫症例の臨床的検討。 日口外誌 38: 1859-1866 1992.

9) Steg, R.F., Dahlin, D.S., et al.: Malignant Lymphoma of the mandibule and maxillary region. Oral Surg 12: 1281959.

10）難波紘二,佐々木なおみ, 他：悪性リンパ腫分 類をめぐる国際学会の動向. 日本臨床 41: 264226581983. 